\title{
Analysis of 15 years of the National Program for the Control and Eradication of Animal Brucellosis and Tuberculosis, Brazil
}

\author{
Avaliação de 15 anos do Programa Nacional de Controle e \\ Erradicação da Brucelose e Tuberculose, Brasil
}

\author{
José Soares Ferreira Neto ${ }^{1 *}$; Gabriela Bicca da Silveira ${ }^{2}$; Barbara Medeiros Rosa ${ }^{2}$; \\ Vitor Salvador Picão Gonçalves ${ }^{3}$; José Henrique Hildebrand Grisi-Filho'; Marcos \\ Amaku$^{1}$; Ricardo Augusto Dias ${ }^{1}$; Fernando Ferreira ${ }^{1}$; Marcos Bryan Heinemann ${ }^{1}$; \\ Evelise Oliveira Telles ${ }^{1}$; Andrey Pereira Lage ${ }^{4}$
}

\begin{abstract}
In 2001, Brazil launched the National Program for Control and Eradication of Animal Brucellosis and Tuberculosis (PNCEBT). After 15 years, After 15 years, it can be checked that there was mistakes and successes in driving the program, but it is undeniable that in this period, a series of structuring actions was initiated. In addition, a large volume of high-quality epidemiological data were produced, which will allow the country to move forward more rationally and safely in combating these two diseases. Today, Brazil have a sufficient contingent of veterinarians to develop the accreditation of farms and vaccination against brucellosis in all States; all batches of vaccines against brucellosis produced by private laboratories are controlled by an official laboratory; the brucellosis vaccination program is well established in most States and it has produced a decrease in prevalence in Mato Grosso, Mato Grosso do Sul, Rondônia and Minas Gerais; there are two ongoing eradication experiences: of brucellosis in Santa Catarina and of tuberculosis in Mato Grosso; nowadays there is a culture to combat brucellosis and tuberculosis in the Brazilian Official Veterinary Services. The epidemiological situation of bovine brucellosis and tuberculosis is well known in the major part of the country. However, progress has been limited by the difficulty in engaging the beef and dairy productive chains as true partners in the process. Key words: Bovine tuberculosis. Bovine brucellosis. Control, Eradication program, Brazil.
\end{abstract}

\section{Resumo}

O Brasil lançou, em 2001, o Programa Nacional de Controle e Erradicação da Brucelose e Tuberculose (PNCEBT). Passados 15 anos, pode-se verificar que houve erros e acertos na condução do programa, porém é inegável que nesse período foi iniciada uma série de ações estruturantes, bem como produzido um grande volume de informações epidemiológicas de alta qualidade que permitirão ao País avançar com mais racionalidade e segurança no combate a essas duas doenças. Já existe um contingente suficiente de médicos veterinários para desenvolver a certificação de propriedades e a vacinação contra brucelose

\footnotetext{
1 Profs., Faculdade de Medicina Veterinária e Zootecnia, Universidade de São Paulo, USP, São Paulo, SP, Brasil. E-mail: grisi@ vps.fmvz.usp.br; fernando@vps.fmvz.usp.br; amaku@vps.fmvz.usp.br; dias@vps.fmvz.usp.br; evelise@vps.fmvz.usp.br; marcosbryan@usp.br; jsoares@vps.fmvz.usp.br

2 Auditoras Fiscais Federais Agropecuárias, Ministério da Agricultura, Pecuária e Abastecimento, MAPA, Brasília, DF, Brasil. E-mail: gabriela.silveira@agricultura.gov.br, barbara.rosa@agricultura.gov.br

3 Prof., Faculdade de Agronomia e Medicina Veterinária, Universidade de Brasília, UnB, Brasília, DF, Brasil. E-mail: vitorspg@ unb.br

4 Prof., Escola de Veterinária, Universidade Federal de Minas Gerais, Belo Horizonte, MG, Brasil. E-mail: aplage11@gmail.com

* Author for correspondence
} 
em todos os Estados; todos os lotes de vacinas contra brucelose produzidos por laboratórios privados são controlados por laboratório oficial; o programa de vacinação contra brucelose está bem implantado na maioria dos Estados e já produziu a diminuição da prevalência nos Estados de Mato Grosso, Mato Grosso do Sul, Rondônia e Minas Gerais; existem duas experiências de erradicação em curso: de brucelose em Santa Catarina e de tuberculose em Mato Grosso; hoje existe uma cultura de combate à brucelose e à tuberculose nos Serviços Veterinários Oficiais dos Estados e da Federação. A situação epidemiológica da tuberculose bovina é conhecida em detalhes em 13 Estados e a da brucelose bovina em 18. No entanto, a evolução tem sido limitada pela dificuldade em engajar as cadeias produtivas de carne e leite como verdadeiros parceiros no processo.

Palavras-chave: Tuberculose bovina. Brucelose bovina. Controle. Erradicação. Programa. Brasil.

\section{Introduction}

In 2001, Brazil launched the National Program for the Control and Eradication of Animal Brucellosis and Tuberculosis (PNCEBT). This novel program was established and was later assisted by an Advisory Scientific Committee that included staff from the Ministry of Agriculture, Livestock and Supply (MAPA) as well as experts from various educational and research institutions in Brazil. This group has also collaborated with foreign researchers and individuals with recognized expertise in this area.

After 15 years, we can identify the errors and successes of the program, but it is undeniable that in this period, a series of structuring actions was initiated, and a large volume of high-quality epidemiological data were produced, which will allow the country to move forward more rationally and safely in combating these two diseases. However, progress has been limited by the difficulty in engaging the beef and dairy productive chains as true partners in the process.

Some of the structuring actions include the accreditation of veterinarians to perform diagnostic tests for brucellosis and tuberculosis and implementation of farm free-accreditation processes, registration of professionals for vaccination of heifers against brucellosis, official control of all batches of vaccines against brucellosis produced by private laboratories, deployment of a consistent vaccination program against brucellosis in the vast majority of the States, and, finally and most importantly, the creation and development of an anti-brucellosis and tuberculosis culture in the Official Veterinary Services of the States and the Federation.

High-quality epidemiological data has revealed details regarding the status of brucellosis in 18 federative units, which contain approximately $85 \%$ of the Brazilian bovine herd. Of these, eight conducted a second study on brucellosis to verify the effectiveness of the implemented measures, in order to improve management of the control/ eradication processes.

With regard to tuberculosis, studies have detailed the epidemiological status in 13 states, which include $75 \%$ of the Brazilian bovine herd.

This epidemiological characterization of brucellosis and tuberculosis in Brazil was coordinated by the Collaborating Centre for Animal Health of MAPA, which is based in the Faculty of Veterinary Medicine and Animal Science (FMVZ) of the University of São Paulo (USP).

\section{Epidemiological Status of Brucellosis}

In 2009, a special supplement of the Arquivo Brasileiro de Medicina Veterinária e Zootecnia (Brazilian Journal of Veterinary and Animal Science) was published, completely dedicated to the dissemination of initial data on the status of brucellosis in 15 federative units in Brazil, namely: Rio Grande do Sul, Santa Catarina, Paraná, São Paulo, Minas Gerais, Espírito Santo, Rio de Janeiro, Mato Grosso do Sul, Mato Grosso, Rondônia, Goiás, Distrito Federal, Tocantins, Bahia, and 
Sergipe (ALVES et al., 2009; AZEVEDO et al., 2009; CHATE et al., 2009; DIAS et al., 2009a, 2009b; GONÇALVES et al., 2009a, 2009b; KLEIN-GUNNEWIEK et al., 2009; MARVULO et al., 2009; NEGREIROS et al., 2009; OGATA et al., 2009; ROCHA et al., 2009; SIKUSAWA et al.,
2009; SILVA et al., 2009; VILLAR et al., 2009). A 2013 article described the situation in Maranhão (BORBA et al., 2013), and this supplement presents the results for Pernambuco and Paraíba (ALMEIDA et al., 2016; CLEMENTINO et al., 2016). Figure 1 shows a map with the Brazilian federative units.

Figure 1. Brazilian federative units.

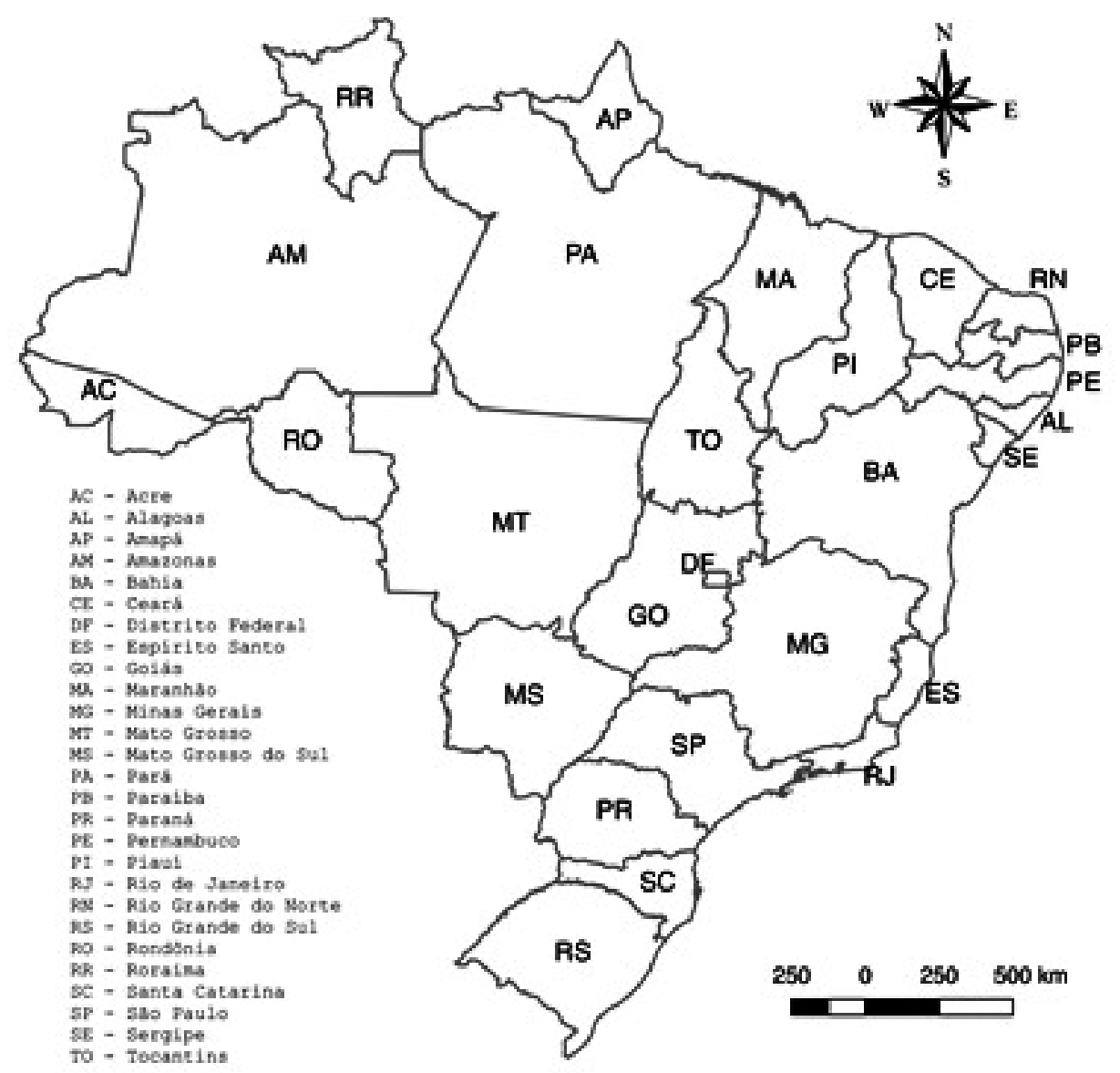

Figures 2 and 3 provide a summary of these findings, showing a great heterogeneity between and within federative units. The highest prevalence of both infected herds and animals tend to be observed in federative units in the Midwest region as well as neighboring states, which are known for beef production. Santa Catarina is the only state with very low prevalence of brucellosis in all regions. It is also a state in which vaccination of heifers with the B19 strain has been prohibited since
2004, and eradication strategies are currently being implemented with the structuring of a surveillance system for detection and mitigation of residual infected herds. The other federative units displayed higher prevalence, consistent with the adoption of vaccination. Therefore, they have implemented vaccination programs based on administration of the B19 strain in order to reduce prevalence rates with the lowest possible cost of investment. 
Figure 2. First standardized studies on the prevalence of brucellosis-seropositive cattle in Brazil.

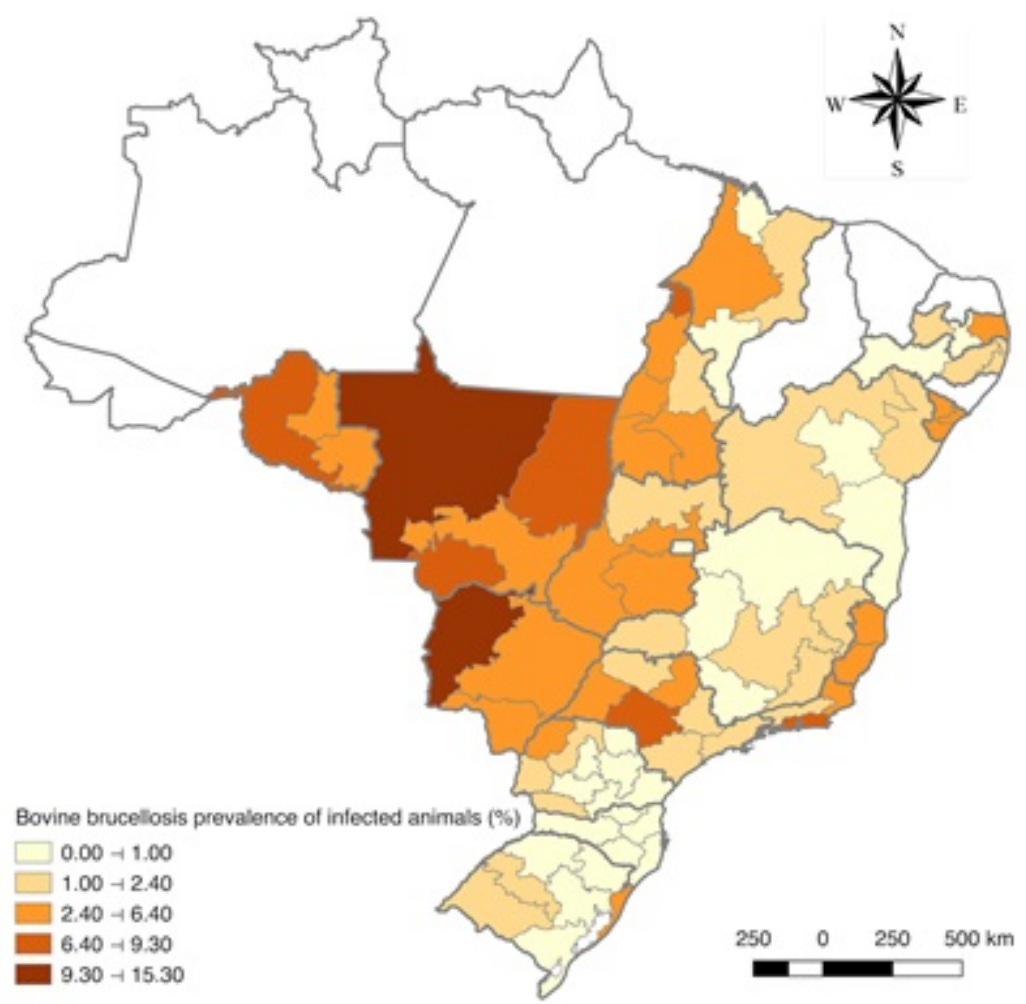

Figure 3. First standardized studies on the prevalence of bovine brucellosis-infected herds in Brazil.

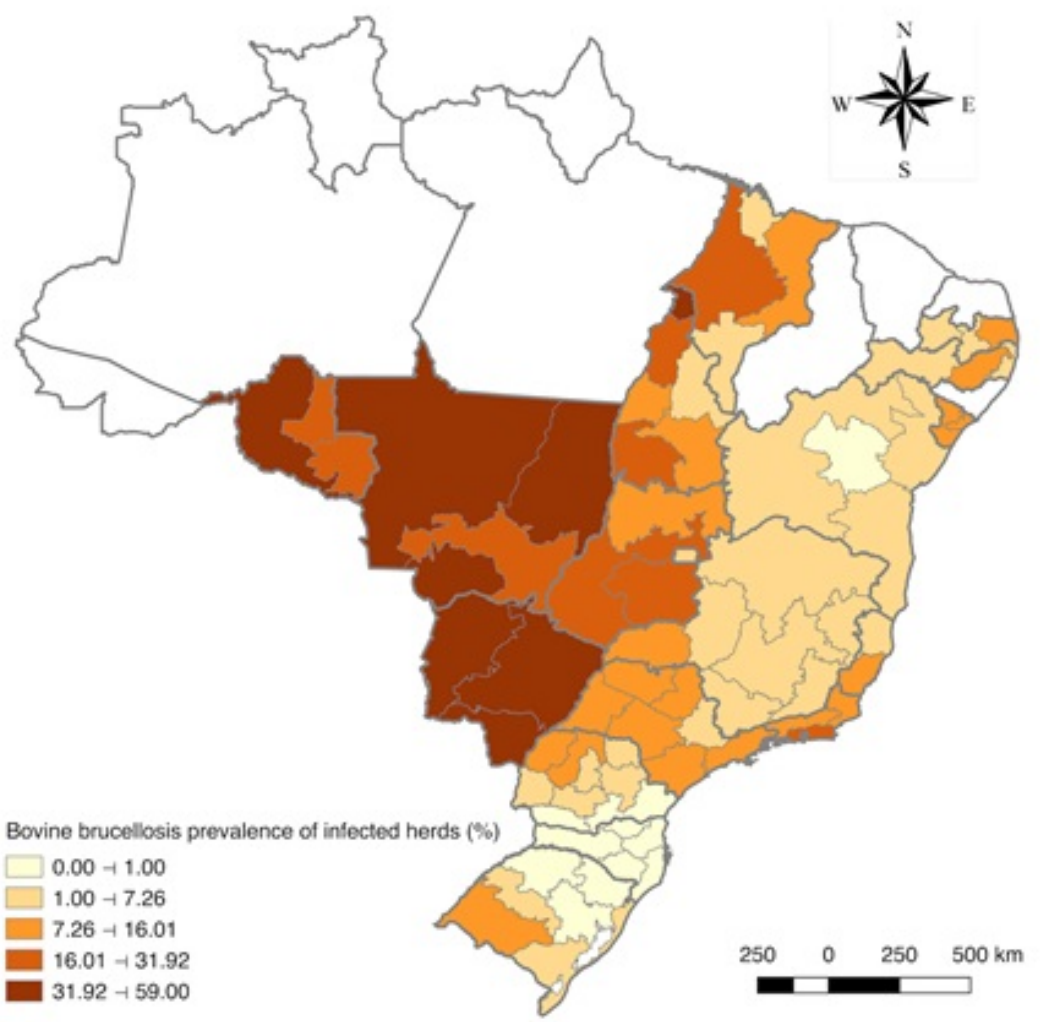


Approximately 10 years after the first study on the epidemiological status of bovine brucellosis, the States of Rondônia, Mato Grosso, Mato Grosso do Sul, São Paulo, Minas Gerais, Espírito Santo, and Rio Grande do Sul carried out a second study to determine whether there was a decrease in the prevalence in accordance with the implemented vaccination programs (BARDDAL et al., 2016; DIAS et al., 2016a; ANZAI et al., 2016; INLAMEA et al., 2016; LEAL FILHO et al., 2016; OLIVEIRA et al., 2016; SILVA et al., 2016b). The state of
Santa Catarina, which has begun implementing an eradication strategy, also performed a second study to estimate the prevalence of brucellosis and to monitor its progress since 2001, when the first study was performed (VILLAR et al., 2009; BAUMGARTEN et al., 2016). Table 1 and Figure 4 show that the vaccination program led to the lowering of the prevalence of infected herds in Minas Gerais, Rondônia, Mato Grosso, and Mato Grosso do Sul. Figures 5 and 6 present the latest prevalence data of bovine brucellosis in the Brazilian federative units.

Table 1. Comparison of the prevalence of bovine brucellosis-infected herds (P) between the first and second studies conducted in Brazilian states, with an interval of approximately 10 years.

\begin{tabular}{lcccccc}
\hline \multirow{2}{*}{ State } & \multicolumn{3}{c}{ First study } & \multicolumn{3}{c}{ Second study } \\
\cline { 2 - 7 } & Year & $\mathrm{P}(\%)$ & $95 \%$ CI (\%) & Year & P (\%) & $95 \%$ CI (\%) \\
\hline Minas Gerais & 2002 & 6.04 & $4.98-7.10$ & 2011 & 3.59 & $2.76-4.42$ \\
Rondônia & 2004 & 35.18 & $32.09-38.36$ & 2014 & 12.3 & $10.3-14.6$ \\
Mato Grosso & 2003 & 41.2 & $38.0-44.4$ & 2014 & 24 & $21.3-26.8$ \\
Mato Grosso do Sul & 1998 & 41.5 & $36.5-44.7$ & 2009 & 30.6 & $27.4-34.0$ \\
Espírito Santo & $2002 / 2003$ & 9.0 & $6.97-11.55$ & $2012 / 2014$ & 9.3 & $7.1-11.8$ \\
Rio Grande do Sul & 2004 & 2.06 & $1.50-2.63$ & 2013 & 3.54 & $2.49-4.88$ \\
São Paulo & 2001 & 9.7 & $7.80-11.60$ & 2011 & 10.2 & $8.8-11.8$ \\
Santa Catarina & 2001 & 0.32 & $0.10-0.69$ & 2012 & 0.91 & $0.30-2.11$ \\
\hline
\end{tabular}

Figure 4. Results of studies on the prevalence of bovine brucellosis-infected herds conducted in Brazilian states, with an interval of approximately 10 years.

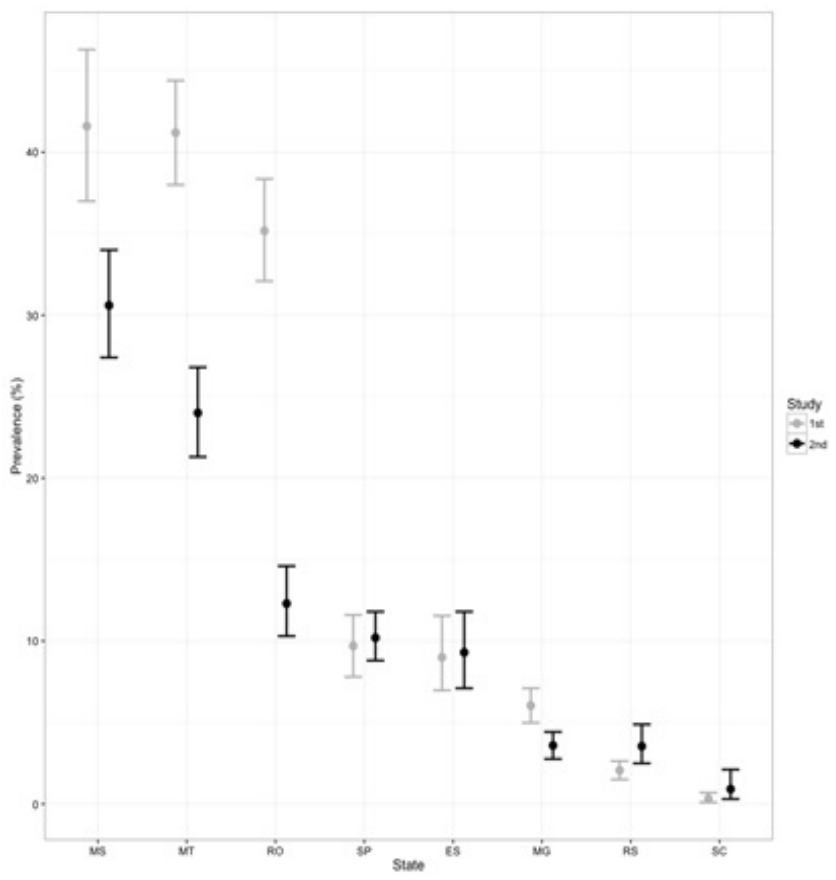


Figure 5. Latest studies on the prevalence of seropositive cows for bovine brucellosis carried out in the Brazilian states (2016).

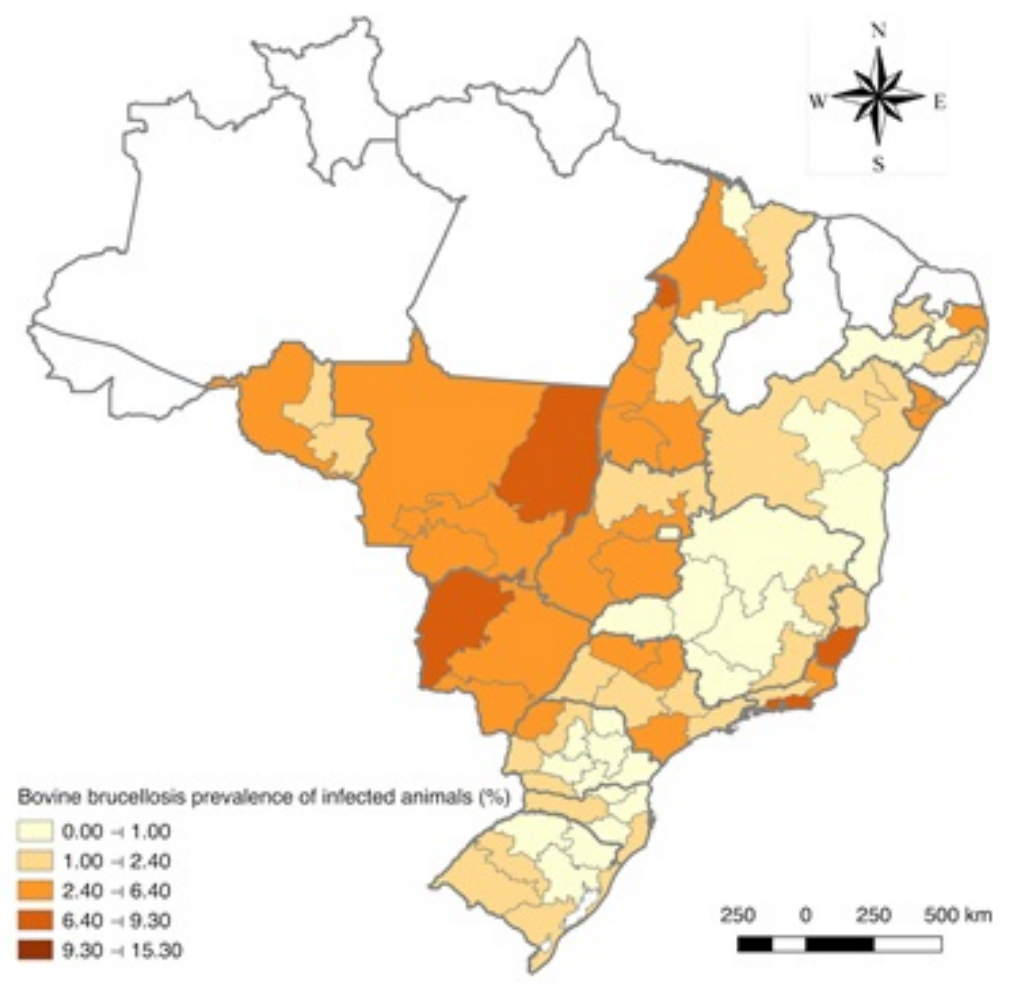

Figure 6. Latest studies on the prevalence of herds infected for bovine brucellosis carried out in the Brazilian states (2016).

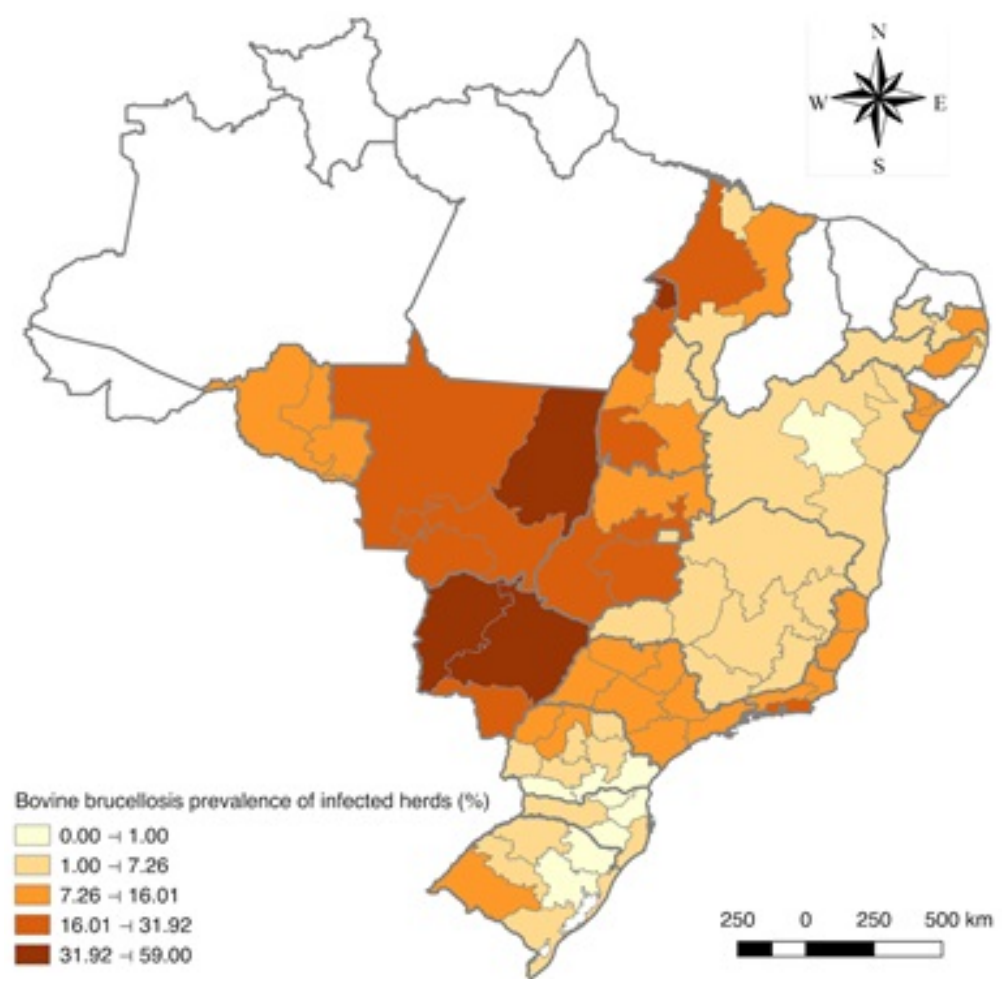


Eighteen of the federative units above have also assessed risk factors for infection; the main variable associated with bovine brucellosis infection was increased herd size (MOTA, 2011). Some traits of larger herds facilitate the transmission of brucellosis, especially the increased replacement of animals (CRAWFORD et al., 1990). Thus, this variable indirectly suggests that replacement of animals, practiced with more frequency in larger herds, is associated with the introduction of the disease on a farm. Another variable systematically identified as a risk factor was the introduction of breeding animals without prior diagnostic testing.

In conclusion, what contributed most to the spread of bovine brucellosis in Brazil was the introduction of animals without testing them, which can be solved with a massive health education program to inform farmers about the importance of testing breeding animals before introduce them in their farms.

\section{Epidemiological Status of Tuberculosis}

This supplement presents the results of the first studies on bovine tuberculosis conducted in 13 federative units, which include $75 \%$ of the Brazilian herd (BAHIENSE et al., 2016; BARBIERI et al., 2016; DIAS et al., 2016b; GALVIS et al., 2016; GUEDES et al., 2016; LIMA et al., 2016; NÉSPOLI et al., 2016; QUEIROZ et al., 2016; RIBEIRO et al., 2016; ROCHA et al., 2016; SILVA et al., 2016a; VELOSO et al., 2016; VENDRAME et al., 2016). The situation is heterogeneous among and within states, as shown in Figures 7 and 8.

Figure 7. Prevalence of tuberculin test-positive cattle in Brazil (2016).

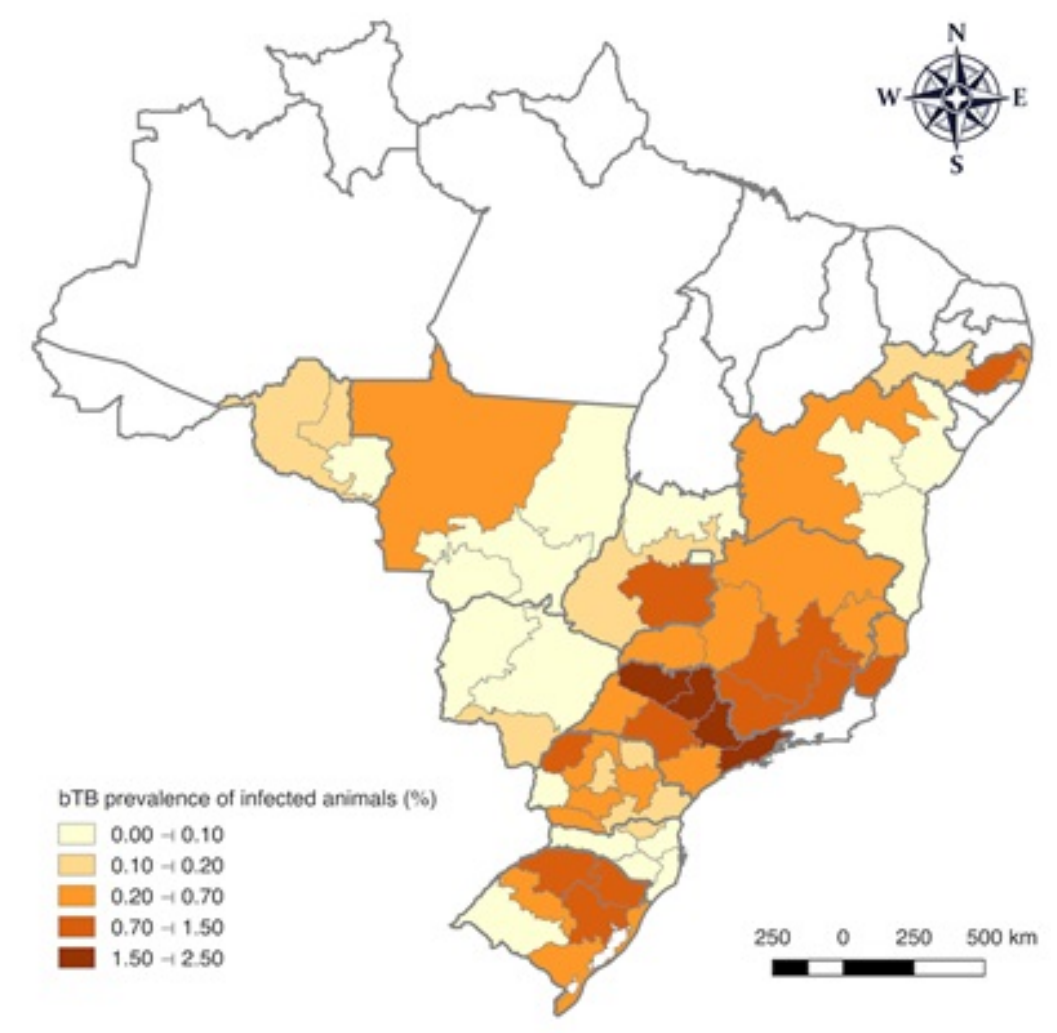


Figures 7 and 8 indicate a higher prevalence in the state of Espírito Santo, north of São Paulo, south of Minas Gerais, and southern Goiás, coinciding with the milk-producing belt in Brazil. Dairy and mixed herds are more vulnerable to tuberculosis, since milk production requires the agglomeration of animals during milking, which increases the risk of transmission (BARLOW et al., 1997), a fact that increases the cattle population density and consequently the likelihood of infectious contacts (HUMBLET et al., 2010; ALVAREZ et al., 2012).

Figure 8. Prevalence of bovine tuberculosis-infected herds in Brazil (2016).

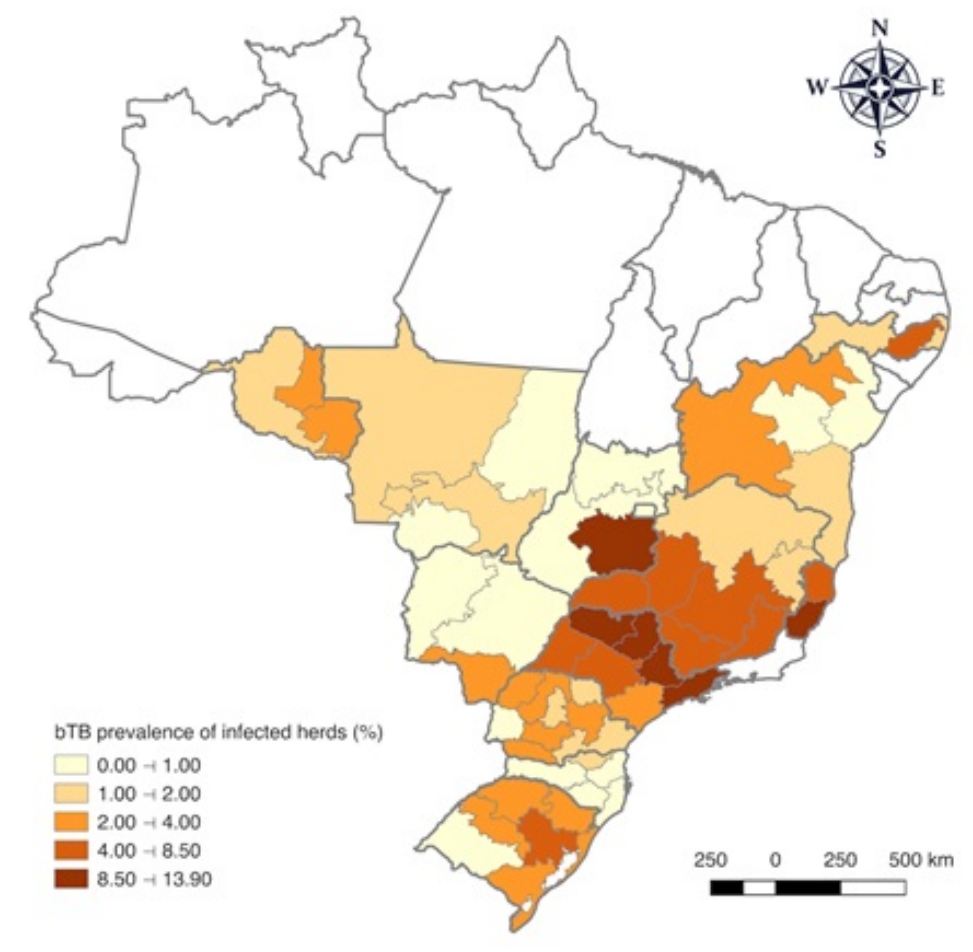

In these 13 states, the main risk factors identified by the studies were milk production, particularly in farms with some degree of sophistication in the mode of production, and having a larger number of cows.

In addition, dairy cattle tend to be older than animals from beef herds, and therefore present a higher probability of disease exposure (HUMBLET et al., 2009). Herds with more sophisticated production modes tend to be denser and their animals more stressed; these factors favor the transmission of tuberculosis (HUMBLET et al., 2009, 2010).

Larger herds have higher replacement rates, thus increasing the risk of introduction of infected animals. The purchase of animals, in particular from high-risk properties, plays an essential role in the transmission of bovine tuberculosis (REILLY; COURTENAY, 2007; OLOYA et al., 2007; TSCHOPP et al., 2009; RAMÍREZVILLAESCUSA et al., 2010; SKUCE et al., 2012; BESSELL et al., 2012). Hence, it is plausible to assume that this variable indicates that the purchase of animals without prior testing increases the risk of introducing bovine tuberculosis to a farm.

In conclusion, bovine tuberculosis in Brazil is more prevalent in dairy farms, especially highproduction farms. The introduction of animals without testing has been the primary contributor 
to this problem, which can be solved with a health education program to inform farmers about the importance of testing animals before introduce them in their farms.

\section{Brucellosis Vaccination}

Vaccination of heifers between three and eight months of age with the B19 strain is compulsory throughout the national territory, except for the state of Santa Catarina, where it is prohibited due to the low prevalence of infected herds $(0.32 \%$ $[0.10,0.69 \%])$ and animals $(0.06 \%$ [0.0-0.17\%]) (SIKUSAWA et al., 2009).

For cows older than eight months, farmers may vaccinate with the non-agglutinogenic or nonantibody-producing vaccine, also known as RB51 (BRASIL, 2007). The adoption of this second, voluntary, vaccine aimed to achieve high vaccine coverage of cows of breeding age in the shortest possible time, since with the B19 strain, because of the age restriction for vaccination, this objective would be achieved only after a time equivalent to the average age of slaughtering reproductive cows.

Figure 9 shows that, since implementation of the PNCEBT, the production of B19 has grown in Brazil, plateauing from 2006. Figure 10 shows the same data for the RB51 vaccine, whose production decreased in 2009 before increasing in 2011. We believe that the lack of farmer interest in the RB51 vaccine was the result of an inefficient dissemination of information regarding the role of the vaccine in the context of the PNCEBT. Currently, this framework is slowly reverting, even with the adoption of this vaccine as an alternative to B19 in areas with challenging management of cows, as in the Pantanal region in the states of Mato Grosso e Mato Grosso do Sul.

Figure 9. Number of B19 doses produced by private laboratories and approved by the Brazilian Official Laboratory (Lanagro-MG), from 2002 to 2014.

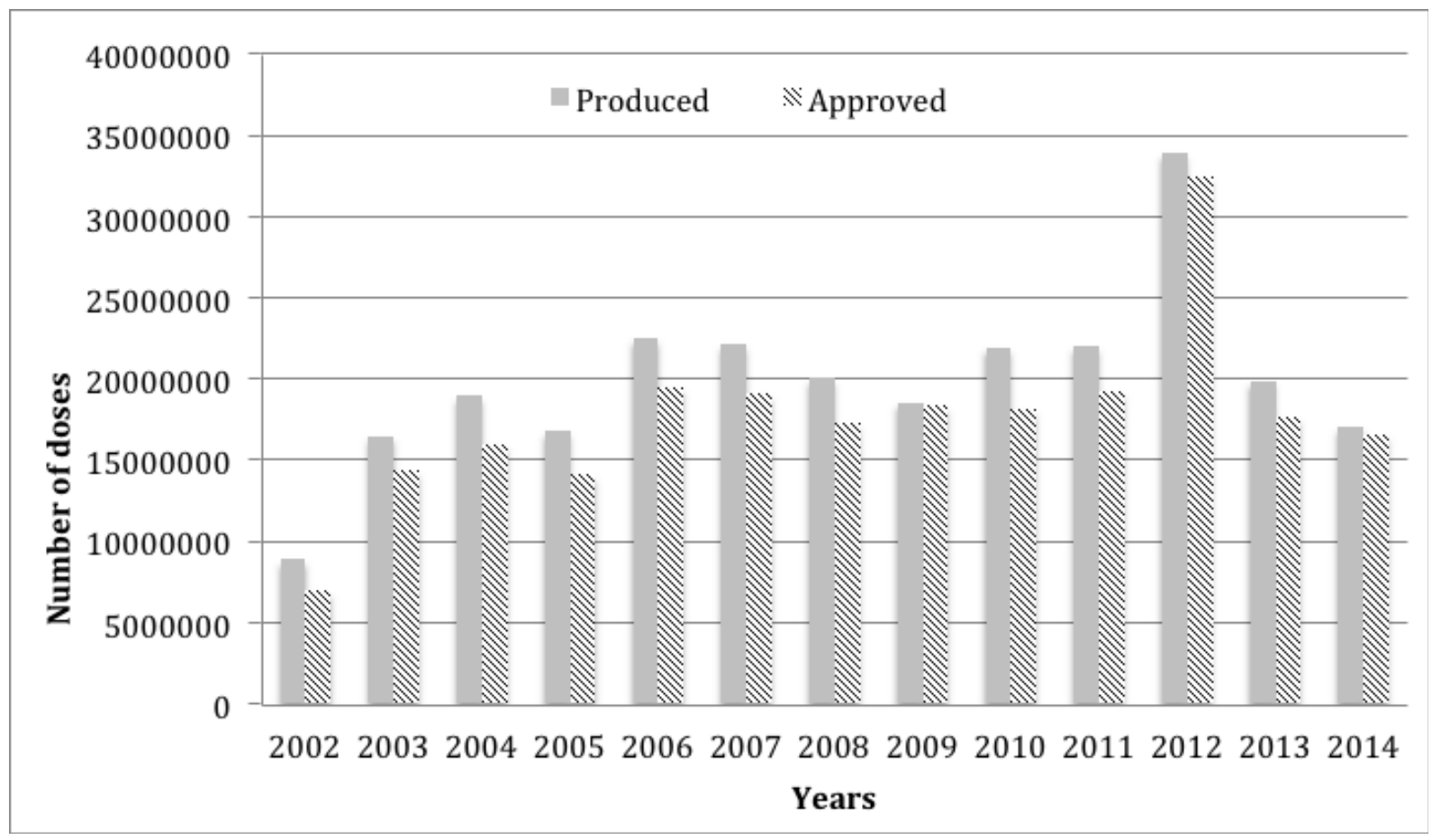


Figure 10. Number of RB51 doses produced by private laboratories and approved by the Brazilian Official Laboratory (Lanagro-MG), from 2008 to 2014.

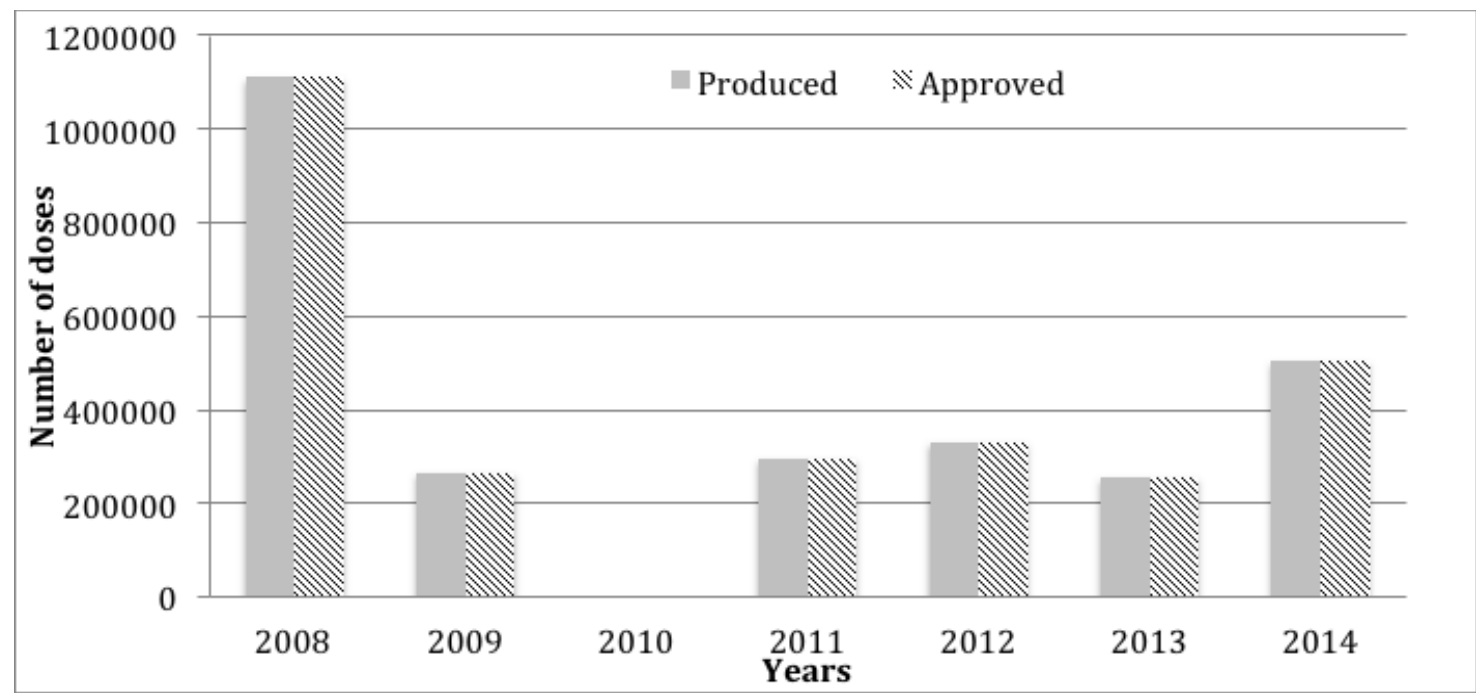

Since the launch of the PNCEBT, there has been a significant increase in the number of heifers vaccinated with B19, especially from 2004 (Figure 11). It is important to stress that there is a large heterogeneity in the quality of the practice among states. Minas Gerais is the best example of success in this country. In 1980 the state had a prevalence of seropositive cows of $6.57 \%$, decreasing to $0.81 \%$ in 2012 through a compulsory vaccination program with the B19 strain launched in 1993 (PAULIN; FERREIRA NETO, 2003; OLIVEIRA et al., 2016). This result is an important example of the impact of B19 on the reduction of the prevalence of bovine brucellosis in the Brazilian productive environment.

Figure 11. Change in the number of heifers vaccinated with the B19 vaccine in Brazil since 2000.

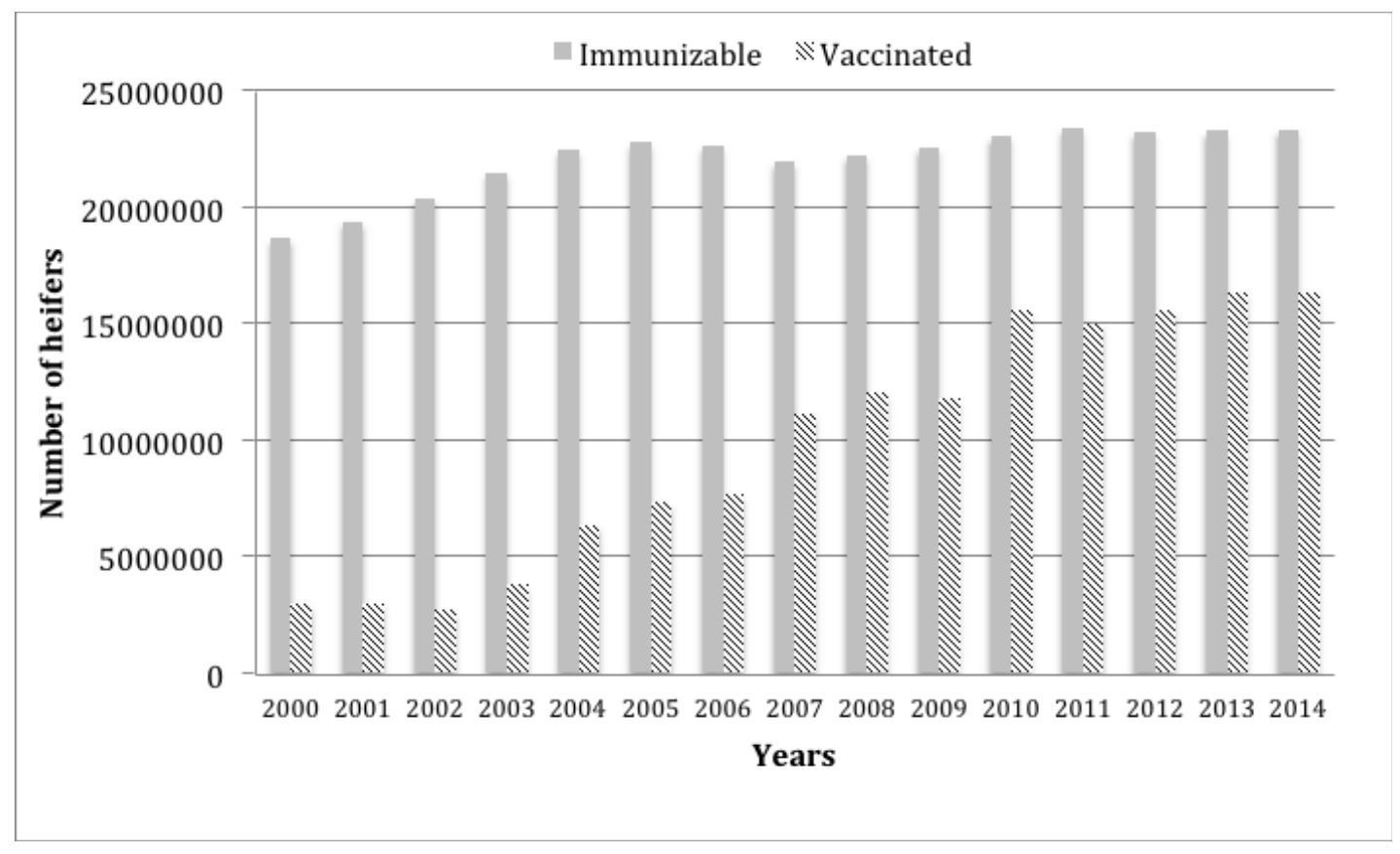




\section{Veterinarian Accreditation}

With the objective of homogenizing conducts and procedures, especially diagnostic procedures, and to disseminate the policies, goals, and initiatives of the PNCEBT, starting in 2001, the MAPA created a accreditation process for veterinarians. To qualify, professionals must pass a course, "Training methods of diagnosis and control of animal brucellosis and tuberculosis and notions of Transmissible Spongiform Encephalopathies (EET)," authorized by the MAPA and facilitated by educational and research institutions nationwide. Table 2 describes the number of authorized institutions offering these courses, as well as accredited veterinarians in the federative units, showing the success of this initiative and good coverage nationwide.

Table 2. Number of institutions authorized by the MAPA to offer training courses and accredited veterinarians in each federative unit in Brazil, 2015.

\begin{tabular}{lcc}
\hline \multicolumn{1}{c}{ Federative unit } & $\begin{array}{c}\text { Institutions authorized by the MAPA to offer accreditation } \\
\text { courses }\end{array}$ & $\begin{array}{c}\text { Accredited veterinarians } \\
\text { Acre }\end{array}$ \\
Alagoas & 1 & 28 \\
Amazonas & 2 & 17 \\
Amapá & 0 & 4 \\
Bahia & 0 & 109 \\
Ceará & 2 & 107 \\
Distrito Federal & 1 & 22 \\
Espírito Santo & 1 & 101 \\
Goiás & 1 & 297 \\
Maranhão & 1 & 82 \\
Minas Gerais & 1 & 736 \\
Mato Grosso do Sul & 5 & 299 \\
Mato Grosso & 4 & 264 \\
Pará & 1 & 127 \\
Paraíba & 2 & 104 \\
Pernambuco & 1 & 87 \\
Piaú & 1 & 25 \\
Paraná & 1 & 794 \\
Rio de Janeiro & 10 & 225 \\
Rio Grande do Norte & 1 & 37 \\
Rondônia & 0 & 68 \\
Roraima & 1 & 1 \\
Rio Grande do Sul & 0 & 594 \\
Santa Catarina & 6 & 394 \\
Sergipe & 1 & 31 \\
São Paulo & 0 & 859 \\
Tocantins & 9 & 51 \\
\hline TOTAL & $\mathbf{5 4}$ & \\
\hline
\end{tabular}




\section{Diagnostic Laboratory Support}

Accredited veterinarians can perform all three tuberculin tests recommended by the PNCEBT for the diagnosis of tuberculosis, as well as screening tests for diagnosis of brucellosis, including the buffered acidified antigen test (BAA) and the milk ring test (MRT) (LAGE et al., 2006). The confirmatory tests for the diagnosis of brucellosis - the complement fixation test and the 2-mercaptoethanol test and fluorescent polarization assay - can be performed only by official laboratories or those accredited by the MAPA (LAGE et al., 2006; BRASIL, 2010). Table 3 shows the location and number of these laboratories, demonstrating the limited size and coverage of this network. However, increased demand for confirmatory tests for the diagnosis of brucellosis will likely lead to a proportional increase in the network of accredited laboratories.

Table 3. Official and MAPA-accredited laboratories for the diagnosis of bovine brucellosis in Brazil, 2015.

\begin{tabular}{lcc}
\hline \multicolumn{1}{c}{ Federative unit } & & Laboratories \\
\cline { 2 - 3 } \multicolumn{1}{c}{ Distrito Federal } & Accredited & Official \\
Goiás & 1 & 0 \\
Maranhão & 1 & 0 \\
Minas Gerais & 1 & 0 \\
Pará & 2 & 1 \\
Paraná & 0 & 1 \\
Rio Grande do Sul & 2 & 0 \\
Santa Catarina & 1 & 0 \\
São Paulo & 1 & 0 \\
\hline Total & 1 & 0 \\
\hline
\end{tabular}

\section{Farm Certification}

Following international guidelines, the PNCEBT recommends a voluntary certification process for disease-free and monitored herds.

The central idea is that the industry, represented by the dairy industry and slaughterhouses, would differently remunerate milk and meat from certified farms, thus stimulating producer adherence due to the non-negligible costs of processing, as reported by economic studies of this issue (LÔBO, 2008; LEITE, 2012). However, this has not happened, and the results of the certification program have been disappointing (Table 4). The lack of compensation funds for replacement of positive animals, found in most federative units by the OIE in the "2014 Evaluation of Veterinary Services in Brazil", considerably limits testing and elimination of positive animals. The best numbers were recorded in the state of Rio Grande do Sul, which triggered a mass municipal certification program, financed in part with public resources. However, the 829 production units certified in this State represent only about $0.25 \%$ of the cattle farms with reproductive activity. 
Table 4. Numbers of certified tuberculosis and brucellosis-free herds in Brazilian federative units, 2015.

\begin{tabular}{lcc}
\hline \multicolumn{1}{c}{ Federative unit } & \multicolumn{2}{c}{ Certified Herds } \\
\cline { 2 - 3 } & Free & Monitored \\
\hline Bahia & 17 & 0 \\
Ceará & 0 & 0 \\
Distrito Federal & 1 & 0 \\
Espírito Santo & 2 & 0 \\
Goiás & 4 & 0 \\
Minas Gerais & 38 & 0 \\
Paraíba & 1 & 0 \\
Pernambuco & 1 & 0 \\
Piauí & 0 & 2 \\
Paraná & 46 & 0 \\
Rio de Janeiro & 3 & 0 \\
Rio Grande do Norte & 1 & 0 \\
Rondônia & 1 & 0 \\
Rio Grande do Sul & 829 & 0 \\
Santa Catarina & 137 & 0 \\
São Paulo & 21 & 1 \\
\hline Total & $\mathbf{1 1 0 2}$ & $\mathbf{3}$ \\
\hline
\end{tabular}

\section{New Directions of the PNCEBT}

Every successful animal health program is dynamic and often has to be updated as the epidemiological situation evolves and new technologies emerge. The PNCEBT was reviewed in 2015 by a working group of the MAPA, which drafted a document, subject to public consultation, which proposed the following:

1) Flexibility in the use of the RB51 vaccine, creating conditions for high levels of vaccination coverage to be achieved in less time, accelerating the reduction of prevalence, as predicted by Souza et al. (2016);

2) Creation of minimum criteria for the sanitization of properties, giving States the option to modulate the routine tests on the basis of the risk of spread of diseases within their territories, which will have special importance for implementation of eradication strategies and surveillance systems;

3) Reduction from three to two tests of negative herds to certify free properties, facilitating adherence of producers to the certification mechanisms;
4) Method for ranking the federative units, taking into account the prevalence and the actions implemented, ranking States in accordance with the degree of risk in relation to animal brucellosis and tuberculosis. The aim is to create a simple indicator for comparison between federative units, fostering exchange of experiences and healthy competition.

\section{Conclusions}

The structuring actions implemented by the PNCEBT produced satisfactory results. We have a sufficient number of veterinarians qualified to certify properties and enrolled for vaccination against brucellosis in all federative units; all batches of vaccine against brucellosis produced by private laboratories are controlled by official laboratories; the vaccination program against bovine brucellosis is well-established in most States; and there is now a culture of combating brucellosis and tuberculosis in the Brazilian Official Veterinary Services.

Since 2004, there has been a significant increase in the number of heifers vaccinated with the B19 
vaccine, although a large heterogeneity persists in the quality of the practice among states. Minas Gerais, having begun its compulsory vaccination program in 1993, has significantly reduced the prevalence of brucellosis-infected animals and herds, generating reference data on the impact of B19 in the Brazilian production environment. The higher the vaccination coverage, the faster the reduction of prevalence (AMAKU et al., 2009. The lack of interest of the farmers in the RB51 vaccine is the result of an inefficient dissemination of the role of this vaccine in the context of the PNCEBT. However, this situation is slowly reversing and RB51 was even adopted as an alternative to B19 in areas of difficult management of cows, such as in the Pantanal. We believe that the quality of the vaccination program in the states can be improved by a massive health education program with a focus on farmers and coercive measures to noncompliers. Cross-sectional studies on brucellosis in the federative units have served as an important tool for the management of this process, because they robustly assess the effects of the quality of vaccination programs on lowering the prevalence of brucellosis.

Santa Catarina is the only state that meets the conditions for implementation of strategies for the eradication of brucellosis, as it presents very low prevalence in all regions. Thus, vaccination with B19 was banned and a surveillance system is being structured to detect and mitigate residual infected herds, which could serve as a model for the rest of the country.

With regard to bovine tuberculosis, higher prevalence was observed in the large dairy belt in Brazil, represented by the state of Espírito Santo, northern São Paulo, Southern Minas Gerais and Eastern Central of Goiás. Prevalence rates are low in the rest of the country, especially in those area more specialized in beef production. Throughout the country, bovine tuberculosis is more concentrated in dairy herds, especially high-production ones and the introduction of new animals without testing is the primary risk factor associated with its spread. Thus, states that wish to move quickly in their fight against bovine tuberculosis should build surveillance systems for the detection and mitigation of infected herds, preferably incorporating elements of riskbased surveillance. Mato Grosso is a pioneer in the implementation of a surveillance system for bovine tuberculosis; its experience could serve as a model for the rest of the country.

For both diseases, a very well structured health education program should be initiated to encourage farmers perform diagnostic tests before introducing breeding animals to their herds.

The certification program of herds, which is voluntary and entails a large cost for the farmers, unfortunately has not produced satisfactory results, because dairy and beef industries do not differently compensate products from certified herds. It is reasonable to assume that the herd certification process would benefit greatly from the establishment of compensation funds to support the replacement of positive animals, as well as marketing actions aimed at the consumers of dairy and beef, encouraging them to prefer products from brucellosis and tuberculosis-free herds. Of course, this process would depend on the simultaneous adoption of a seal of sanitary quality stamped on products, increasing the added value of the products and allowing for better compensation for the producers of certified properties.

In conclusion, recent changes in the PNCEBT will allow to achieve high levels of vaccination coverage in less time; will enable the states to modulate the routine of testing according to the risk of spread of diseases in their territories; will reduce the costs of certification of disease-free herds; and will allow more direct comparison of the epidemiological status between the federative units, which will foster the exchange of experience as well as healthy competition. 


\section{Acknowledgements}

The authors acknowledge the logistical and financial support from MAPA, Brazilian Official Veterinary Services, CAPES, CNPq and FAPESP.

\section{References}

ALMEIDA, E. C.; FREITAS, A. A.; PONTUAL, K. A. Q.; SOUZA, M. M. A.; AMAKU, M.; DIAS, R. A.; FERREIRA, F.; TELLES, E. O.; HEINEMANN, M. B.; GONÇALVES, V. S. P.; EVÊNCIO NETO, J.; MARVULO, M. F. V.; GRISI-FILHO, J. H. H.; FERREIRA NETO, J. S.; SILVA, J. C. R. Prevalence and associated risk factors for bovine brucellosis in the state of Pernambuco, Brazil. Semina: Ciências Agrárias, Londrina, v. 37, n. 5, p. 3413-3424, 2016. Suplemento 2.

ALVAREZ, J.; PEREZ, A M.; BEZOS, J.; CASAL, C.; ROMERO, B.; RODRIGUEZ-CAMPOS, S.; SAEZLLORENTE, J. L.; DIAZ, R.; CARPINTERO, J.; DE JUAN, L.; DOMÍNGUEZ, L. Eradication of bovine tuberculosis at a herd-level in Madrid, Spain: study of within-herd transmission dynamics over a 12 year period. BMC Veterinary Research, v. 8, n. 100, p. 2-8, 2012. Available in: <http://www.biomedcentral.com/content/ pdf/1746-6148-8-100.pdf>. Accessed at: 05 july 2016.

ALVES, A. J. S.; GONÇALVES, V. P. S.; FIGUEIREDO, V. C. F.; LOBO, J. R.; BAHIENSE, L.; AMAKU, M.; FERNANDO, F.; FERREIRA NETO, J. S.; DIAS, R. A. Situação epidemiológica da brucelose bovina no Estado da Bahia. Arquivo Brasileiro de Medicina Veterinária e Zootecnia, Belo Horizonte, v. 61, p. 6-13, 2009. Suplemento 1.

AMAKU, M.; DIAS, R.; FERREIRA NETO, J.; FERREIRA, F. Modelagem matemática do controle de brucelose bovina por vacinação. Arquivo Brasileiro de Medicina Veterinária e Zootecnia, Belo Horizonte, v. 61, p. 135-141, 2009. Suplemento 1.

ANZAI, E. K.; COSTA, D.; SAID, A. L. P. R.; GRISI-FILHO, J. H. H.; AMAKU, M.; DIAS, R. A.; FERREIRA, F.; GALVIS, J. O. A.; GONÇALVES, V. S. P.; HEINEMANN, M. B.; TELLES, E. O.; FERREIRA NETO, J. S. An update on the epidemiological situation of bovine brucellosis in the state of Espírito Santo, Brazil. Semina: Ciências Agrárias, Londrina, v. 37, n. 5, p. 3437-3448, 2016. Suplemento 2.

AZEVEDO, S. S.; FERREIRA NETO, J. S.; DIAS, R. A.; FERREIRA, F.; AMAKU, M.; FIGUEIREDO, V. C. F.; LOBO, J. R.; GONÇALVES, V. S. P.; SOUZA, A. C.; VASCONCELLOS, S. A. Situação epidemiológica da brucelose bovina no Estado do Espírito Santo. Arquivo Brasileiro de Medicina Veterinária e Zootecnia, Belo Horizonte, v. 61, p. 19-26, 2009. Suplemento 1.
BAHIENSE, L.; ÁVILA, L. N. de; BAVIA, M. E.; AMAKU, M.; DIAS, R. A.; GRISI-FILHO, J. H. H.; FERREIRA, F.; TELLES, E. O.; GONÇALVES, V. S. P.; HEINEMANN, M. B.; FERREIRA NETO, J. S. Prevalence and risk factors for bovine tuberculosis in the State of Bahia, Brazil. Semina: Ciências Agrárias, Londrina, v. 37, n. 5, p. 3549-3560, 2016. Suplemento 2.

BARBIERI, J. M.; OLIVEIRA, L. F.; DORNELES, E. M. S.; MOTA, A. L. A. A.; GONÇALVES, V. S. P.; MALUF, P. P.; FERREIRA NETO, J. S.; FERREIRA, F.; DIAS, R. A.; TELLES, E. O.; GRISI-FILHO, J. H. H.; HEINEMANN, M. B.; AMAKU, M.; LAGE, A. P. Epidemiological status of bovine tuberculosis in the state of Minas Gerais, Brazil, 2013. Semina: Ciências Agrárias, Londrina, v. 37, n. 5, p. 3531-3548, 2016. Suplemento 2.

BARDDAL, J. E. I.; SANTOS, J. C. Q.; LOPES, I. F.; FERREIRA NETO, J. S.; FERREIRA, F.; AMAKU, M.; DIAS, R. A.; TELLES, E. O.; GRISI-FILHO, J. H. H.; HEINEMANN, M. B.; GONÇALVES, V. S. P.; AGUIAR, D. M. Effect of vaccination in lowering the prevalence of bovine brucellosis in the state of Mato Grosso, Brazil. Semina: Ciências Agrárias, Londrina, v. 37, n. 5, p. 3479-3492, 2016. Suplemento 2.

BARLOW, N. D.; KEAN, J. M.; HICKLING, G.; LIVINGSTONE, P. G.; ROBSON, A. B. A simulation model for the spread of bovine tuberculosis within New Zealand cattle herds. Preventive Veterinary Medicine, v. 32, n. 1-2, p. 57-75, 1997.

BAUMGARTEN, K. D.; VELOSO, F. P.; GRISI-FILHO, J. H. H.; FERREIRA, F.; AMAKU, M.; DIAS, R. A.; TELLES, E. O.; HEINEMANN, M. B.; GONÇALVES, V. S.; FERREIRA NETO, J. S. Prevalence and risk factors for bovine brucellosis in the State of Santa Catarina, Brazil. Semina: Ciências Agrárias, Londrina, v. 37, n. 5, p. 3425-3436, 2016. Suplemento 2.

BESSELL, P. R.; ORTON, R.; WHITE, P. C. L.; HUTCHINGS, M. R.; KAO, R. R. Risk factors for bovine Tuberculosis at the national level in Great Britain. $B M C$ Veterinary Research, v. 8, p. 51, 2012. Available at: <http:/www.biomedcentral.com/1746-6148/8/51>. Accessed at: 05 july 2016.

BORBA, M. R.; STEVENSON, M. A.; GONÇALVES, V. S. P.; FERREIRA NETO, J. S.; FERREIRA, F.; AMAKU, M.; TELLES, E. O.; SANTANA, S. S.; FERREIRA, J. C. A.; LOBO, J. R.; FIGUEIREDO, V. C. F.; DIAS, R. A. Prevalence and risk-mapping of bovine brucellosis in Maranhão state, Brazil. Preventive Veterinary Medicine, Colorado, v. 110, n. 2, p. 169-176, 2013.

BRASIL. Ministério da Agricultura, Pecuária e Abastecimento. Instrução Normativa $n^{\circ}$. 27, de 20 de outubro de 2010. Aprova o teste de polarização fluorescente (TPF) para utilização pelo Programa 
Nacional de Controle e Erradicação da Brucelose e Tuberculose animal no diagnóstico da brucelose bovina e bubalina. Diário Oficial [da] União, Brasília, 22 out. 2010, Seção 1.

Ministério da Agricultura, Pecuária e Abastecimento. Instrução Normativa $n^{\circ} .33$, de 24 de agosto de 2007. Estabelece condições para vacinação de fêmeas bovinas contra a brucelose, utilizando vacina não indutora de formação de anticorpos aglutinante, amostra RB51. Diário Oficial [da] União, Brasília, 28 ago. 2007, Seção 1.

CHATE, S. C.; DIAS, R. A.; AMAKU, M.; FERREIRA, F.; MORAES, G. M.; COSTA NETO, A. A.; MONTEIRO, L. A. R. C.; LOBO, J. R.; FIGUEIREDO, V. C. F.; GONÇALVES, V. S. P.; FERREIRA NETO, J. S. Situação epidemiológica da brucelose bovina no Estado do Mato Grosso do Sul. Arquivo Brasileiro de Medicina Veterinária e Zootecnia, Belo Horizonte, v. 61, p. 46-55, 2009. Suplemento 1.

CLEMENTINO, I. J.; DIAS, R. A.; AMAKU, M.; FERREIRA, F.; TELLES, E. O.; HEINEMANN, M. B.; GONÇALVES, V. S. P.; GRISI-FILHO, J. H. H.; FERREIRA NETO, J. S.; ALVES, C. J.; SANTOS, C. S. A. B.; AZEVEDO, S. S. Epidemiological situation of bovine brucellosis in the state of Paraiba, Brazil. Semina: Ciências Agrárias, Londrina, v. 37, n. 5, p. 3403-3412, 2016. Suplemento 2.

CRAWFORD, R. P.; HUBER, J. D.; ADAMS, B. S. Epidemiology and surveillance. In: NIELSEN, K.; DUNCAN, J. R. (Ed.). Animal brucellosis. Boca Raton: CRC Press, 1990. p. 131-151.

DIAS, J. A.; MÜLLER, E. E.; DIAS, R. A.; FREITAS, J. C.; AMAKU, M.; FERREIRA, F.; SILVA, M. C. P.; LOBO, J. R.; FIGUEIREDO, V. C. F.; GONÇALVES, V. S. P.; FERREIRA, NETO, J. S. Situação epidemiológica da brucelose bovina no Estado do Paraná. Arquivo Brasileiro de Medicina Veterinária e Zootecnia, Belo Horizonte, v. 61, p. 66-76, 2009a. Suplemento 1.

DIAS, R. A.; BELCHIOR, A. P. C.; FERREIRA, R. S.; GONÇALVES, R. C.; BARÃO. R. S. C.; SOUSA, P. R.; SANTOS, A. M. A.; AMAKU, M.; FERREIRA, F.; TELLES, E. O.; GRISI-FILHO, J. H. H.; HEINEMANN, M. B.; GONÇALVES, V. S. P.; FERREIRA NETO, J. S. Controlling bovine brucellosis in the state of São Paulo, Brazil: results after ten years of a vaccination program. Semina: Ciências Agrárias, Londrina, v. 37, n. 5, p. 3505-3518, 2016a. Suplemento 2.

DIAS, R. A.; GONÇALVES, V. S. P.; FIGUEIREDO, V. C. F.; LOBO, J. R.; LIMA, Z. M. B.; PAULIN, L. M. S.; GUNNEWIEK, M. F. K.; AMAKU, M.; FERREIRA NETO, J. S.; FERREIRA, F. Situação epidemiológica da brucelose bovina no Estado de São Paulo. Arquivo Brasileiro de Medicina Veterinária e Zootecnia, Belo Horizonte, v. 61, p. 118-125, 2009b. Suplemento 1.
DIAS, R. A.; STANOJLOVIC, F. M. U.; BELCHIOR, A. P. C.; FERREIRA, R. S.; GONÇALVES, R. C.; AGUIAR, R. S. C. B.; SOUSA, P. R.; SANTOS, A. M. A.; AMAKU, M.; FERREIRA, F.; TELLES, E. O.; GRISI-FILHO, J. H. H.; GONÇALVES, V. S. P.; HEINEMANN, M. B.; FERREIRA NETO, J. S. Prevalence and risk factors for bovine tuberculosis in the state of São Paulo, Brazil. Semina: Ciências Agrárias, Londrina, v. 37, n. 5, p. 3673-3684, 2016b. Suplemento 2.

GALVIS, J. O. A.; GRISI-FILHO, J. H. H; COSTA, D.; SAID, A. L. P. R.; AMAKU, M.; DIAS, R. A.; FERREIRA, F.; GONÇALVES, V. S. P.; HEINEMANN, M. B.; TELLES, E. O.; FERREIRA NETO, J. S. Epidemiologic characterization of bovine tuberculosis in the state of Espírito Santo, Brazil. Semina: Ciências Agrárias, Londrina, v. 37, n. 5, p. 3567-3578, 2016. Suplemento 2.

GONÇALVES, V. S. P.; DELPHINO, M. K. V. C.; DIAS, R. A.; FERREIRA, F.; AMAKU, M.; FERREIRA NETO, J. S.; PORTO, T. B.; ALVES, C. M.; FIGUEIREDO, V. C. F.; LOBO, J. R. Situação epidemiológica da brucelose bovina no Estado de Minas Gerais. Arquivo Brasileiro de Medicina Veterinária e Zootecnia, Belo Horizonte, v. 61, p. 35-45, 2009a. Suplemento 1.

GONÇALVES, V. S. P.; RIBEIRO, L. A.; CALDAS, R. A.; FRANCISCO, P. F. C.; DIAS, R. A.; FERREIRA, F.; AMAKU, M.; FERREIRA NETO, J. S.; FIGUEIREDO, V. C. F.; LOBO, J. R.; BORGES, J. R. J. Situação epidemiológica da brucelose bovina no Distrito Federal. Arquivo Brasileiro de Medicina Veterinária e Zootecnia, Belo Horizonte, v. 61, p. 14-18, 2009b. Suplemento 1.

GUEDES, I. B.; BOTTENE, I. F. N.; MONTEIRO, L. A. R. C.; LEAL FILHO, J. M.; HEINEMANN, M. B.; AMAKU, M.; GRISI-FILHO, J. H. H.; DIAS, R. A.; FERREIRA, F.; TELLES, E. O.; GONÇALVES, V. S. P.; FERREIRA NETO, J. S. Prevalence and risk factors for bovine tuberculosis in the state of Mato Grosso do Sul, Brazil. Semina: Ciências Agrárias, Londrina, v. 37, n. 5, p. 3579-3588, 2016. Suplemento 2.

HUMBLET,M.F.; BOSCHIROLI,M.L.; SAEGERMAN, C. Classification of worldwide bovine tuberculosis risk factors in cattle: a stratified approach. Veterinary Research, v. 40, n. 5, p. 1-24, 2009. Available at: <http:// www.ncbi.nlm.nih.gov/pmc/articles/PMC2710499>. Accessed at: 05 july 2016 .

HUMBLET, M. F.; GILBERT, M.; GOVAERTS, M.; FAUVILLE-DUFAUX, M.; WALRAVENS, K.; SAEGERMAN, C. New assessment of bovine tuberculosis risk factors in Belgium based on nationwide molecular epidemiology. Journal of Clinical Microbiology, Barcelona, v. 48, n. 8, p. 2802-2808, 2010. Suplemento 1. 
INLAMEA, O. F.; ROCHA, A. B.; FERREIRA, F.; GRISI-FILHO, J. H. H.; HEINEMANN, M. B.; DIAS, R. A.; TELLES, E. O.; GONÇALVES, V. S. P.; AMAKU, M.; FERREIRA NETO, J. S. Effect of vaccination in lowering bovine brucellosis in the state of Rondônia, Brazil. Semina: Ciências Agrárias, Londrina, v. 37, n. 5, p. 3493-3506, 2016. Suplemento 2.

KLEIN-GUNNEWIEK, M. F. C.; AMAKU, M.; DIAS, R. A.; FERREIRA, F.; GITTI, C. B.; PEREIRA, L. A.; FIGUEIREDO, V. C. F.; LOBO, J. R.; GONÇALVES, V. S. P.; FERREIRA NETO J. S. Situação epidemiológica da brucelose bovina no Estado do Rio de Janeiro. Arquivo Brasileiro de Medicina Veterinária e Zootecnia, Belo Horizonte, v. 61, p. 77-84, 2009. Suplemento 1.

LAGE, A. P.; ROXO, E.; MÜLlER, E.; POESTER, F.; CAVALLÉRO, J. C. M.; FERREIRA NETO, J. S.; MOTA, P. M. P. C.; GONÇALVES, V. S. P. Programa nacional de controle e erradicação da brucelose e da tuberculose animal (PNCEBT). Brasília: Ministério da Agricultura, Pecuária e Abastecimento, 2006. 184 p. (Manual técnico).

LEAL FILHO, J. M.; BOTTENE, I. F. N.; MONTEIRO, L. A. R. C.; PELLEGRIN, A. O.; GONÇALVES, V. S. P.; FERREIRA, F.; DIAS, R. A.; AMAKU, M.; TELLES, E. O.; GRISI-FILHO, J. H. H.; HEINEMANN, M. B.; FERREIRA NETO, J. S. Control of bovine brucellosis from 1998 to 2009 in the state of Mato Grosso do Sul, Brazil. Semina: Ciências Agrárias, Londrina, v. 37, n. 5, p. 3467-3478, 2016. Suplemento 2.

LEITE, B. M. Aspectos epidemiológicos e econômicos da certificação de propriedades leiteiras como livres de brucelose e tuberculose bovina. 2012. Dissertação (Mestrado em Saúde Animal) - Faculdade de Agronomia e Medicina Veterinária. Universidade de Brasília, Brasília.

LIMA, P. B.; NASCIMENTO, D. L.; ALMEIDA, E. C.; PONTUAL, K. A. Q.; AMAKU, M.; DIAS, R. A.; FERREIRA, F.; GONÇALVES, V. S. P.; TELLES, E. O.; GRISI-FILHO, J. H. H.; HEINEMANN, M. B.; SILVA, J. C. R.; FERREIRA NETO, J. S. Epidemiological situation of bovine tuberculosis in the state of Pernambuco, Brazil. Semina: Ciências Agrárias, Londrina, v. 37, n. 5, p. 3601-3610, 2016. Suplemento 2.

LÔBO, J. R. Análise custo-benefício da certificação de propriedades livres de tuberculose. 2008. Dissertação (Mestrado em Agronegócios) - Faculdade de Agronomia e Medicina Veterinária. Universidade de Brasília, Brasília.

MARVULO, M. F. V.; FERREIRA, F.; DIAS, R. A.; AMAKU, M.; GROFF, A. C. M.; GONÇALVES, V. S. P.; FIGUEIREDO, V. C. F.; LOBO, J. R.; FERREIRA, NETO J. S. Situação epidemiológica da brucelose bovina no Estado do Rio Grande do Sul. Arquivo Brasileiro de Medicina Veterinária e Zootecnia, Belo Horizonte, v. 61, p. 93-102, 2009. Suplemento 1.

MOTA, A. L. A. A. Fatores de risco para brucelose bovina no Brasil. 2011. Dissertação (Mestrado em Saúde Animal) - Faculdade de Agronomia e Medicina Veterinária, Universidade Federal de Brasília, Brasília.

NEGREIROS, R. L.; DIAS, R. A.; FERREIRA, F.; FERREIRA NETO, J. S.; GONCALVES, V. S. P.; SILVA, M. C. P.; FIGUEIREDO, V. C. F.; LOBO, J. R.; FREITAS, J.; AMAKU, M. Situação epidemiológica da brucelose bovina no Estado do Mato Grosso. Arquivo Brasileiro de Medicina Veterinária e Zootecnia, Belo Horizonte, v. 61, p. 56-65, 2009. Suplemento 1.

NÉSPOLI, J. M. B.; NEGREIROS, R. L.; AMAKU, M.; DIAS, R. A.; FERREIRA, F.; TELLES, E. O.; HEINEMANN, M. B.; GRISI-FILHO, J. H. H.; GONÇALVES, V. S. P.; FERREIRA NETO, J. S. Epidemiological situation of bovine tuberculosis in the state of Mato Grosso, Brazil. Semina: Ciências Agrárias, Londrina, v. 37, n. 5, p. 3589-3600, 2016. Suplemento 2.

OGATA, R. A.; GONÇALVES, V. S. P.; FIGUEIREDO, V. C. F.; LOBO, J. R.; RODRIGUES, A. L.; AMAKU, M.; FERREIRA, F.; FERREIRA NETO, J. S.; DIAS, R. A. Situação epidemiológica da brucelose bovina no Estado do Tocantins. Arquivo Brasileiro de Medicina Veterinária e Zootecnia, Belo Horizonte, v. 61, p. 126134, 2009. Suplemento 1.

OLIVEIRA, L. F.; DORNELES, E. M. S.; MOTA, A. L. A. A.; GONÇALVES, V. S. P.; FERREIRA NETO, J. S.; FERREIRA, F.; DIAS, R. A.; TELLES, E. O.; GRISIFILHO, J. H. H.; HEINEMANN, M. B.; AMAKU, M.; LAGE, A. P Seroprevalence and risk factors for bovine brucellosis in Minas Gerais State, Brazil. Semina: Ciências Agrárias, Londrina, v. 37, n. 5, p. 3449-3446, 2016. Suplemento 2.

OLOYA, J.; MUMA, J. B.; OPUDA-ASIBO, J.; DJØNNE，B.; KAZWALA，R.; SKJERVE, E. Risk factors for herd-level bovine-tuberculosis seropositivity in transhumant cattle in Uganda. Preventive Veterinary Medicine, v. 80, n. 4, p. 318-329, 2007.

PAULIN, L. M.; FERREIRA NETO, J. S. O combate à brucelose bovina: situação brasileira. Jaboticabal: FUNEP, 2003. $154 \mathrm{p}$.

QUEIROZ, M. R.; GROFF, A. C. M.; SILVA, N. S.; GRISI-FILHO, J. H. H.; AMAKU, M.; DIAS, R. A.; TELLES, E. O.; HEINEMANN, M. B.; FERREIRA NETO, J. S.; GONÇALVES, V. S. P. FERREIRA, F. Epidemiological status of bovine tuberculosis in the state of Rio Grande do Sul, Brazil. Semina: Ciências Agrárias, Londrina, v. 37, n. 5, p. 3647-3658, 2016. Suplemento 2. 
RAMÍREZ-VILLAESCUSA, A. M.; MEDLEY, G. F.; MASON, S.; GREEN, L. E. Risk factors for herd breakdown with bovine tuberculosis in 148 cattle herds in the South West of England. Preventive Veterinary Medicine, Colorado, v. 95, p. 224-230, 2010. Suplemento 1.

REILLY, L. A.; COURTENAY, O. Husbandry practices, badger sett density and habitat composition as risk factors for transient and persistent bovine tuberculosis on UK cattle farms. Preventive Veterinary Medicine, Colorado, v. 80, n. 2-3, p. 129-142, 2007.

RIBEIRO, L. A.; GONÇALVES, V. S. P.; FRANCISCO, P. F. C.; MOTA, A. L. A. A.; NASCIMENTO, G. T.; LICURGO, J. B.; FERREIRA, F.; GRISI-FILHO, J. H. H.; FERREIRA NETO, J. S.; AMAKU, M.; DIAS, R. A.; TELLES, E. O.; HEINEMANN, M. B.; BORGES, J. R. J. Epidemiological status of bovine tuberculosis in the Federal District of Brazil. Semina: Ciências Agrárias, Londrina, v. 37, n. 5, p. 3561-3566, 2016. Suplemento 2.

ROCHA, W. V.; JAYME, V. S.; MOTA, A. L. A. A.; BRITO, W. M. E. D; PIRES, G. R. C; GRISI-FILHO, J. H. H; DIAS, R. A.; AMAKU, M.; TELLES, E. O.; HEINEMANN, M. B.; FERREIRA, F.; FERREIRA NETO, J. S.; GONÇALVES, V. S. P. Prevalence and herd-level risk factors of bovine tuberculosis in the State of Goiás, Brazil. Semina: Ciências Agrárias, Londrina, v. 37 , n. 5 , p. 3625-3628, 2016. Suplemento 2.

ROCHA, W. V.; GONÇALVES, V. S. P.; COELHO, C. G. N. F. L.; BRITO, W. M. E. D.; DIAS, R. A.; DELPHINO, M. K. V. C.; FERREIRA, F.; AMAKU, M.; FERREIRA NETO, J. S.; FIGUEIREDO, V. C. F.; LOBO, J. R.; BRITO, L. A. B. Situação epidemiológica da brucelose bovina no Estado de Goiás. Arquivo Brasileiro de Medicina Veterinária e Zootecnia, Belo Horizonte, v. 61, p. 27-34, 2009. Suplemento 1.

SIKUSAWA, S.; AMAKU, M.; DIAS, R. A.; FERREIRA NETO, J. S.; MARTINS, C.; GONÇALVES, V. S. P.; FIGUEIREDO, V. C. F. Arquivo Brasileiro de Medicina Veterinária e Zootecnia, Belo Horizonte, v. 61, p. 103108, 2009. Suplemento 1.

SILVA, M. C. P.; GONÇALVES, V. S. P.; MOTA, A. L. A. A.; KOLODA, M.; FERREIRA NETO, J. S.; GRISIFILHO, J. H. H; DIAS, R. A.; AMAKU, M.; TELLES, E. O.; FERREIRA, F.; HEINEMANN, M. B.; ALFIERI, A. A.; MULLER, E. E. Prevalence and herd-level risk factors for bovine tuberculosis in the state of Paraná, Brazil. Semina: Ciências Agrárias, Londrina, v. 37, n. 5, p. 3611-3624, 2016. Suplemento 2.

SILVA, N. S.; GROFF, A. C. M.; VIDOR, A. C. M.; GRISI-FILHO, J. H. H.; HEINEMANN, M. B.; DIAS, R. A.; TELLES, E. O.; GONÇALVES, V. S. P.; AMAKU, M.; FERREIRA, F.; FERREIRA NETO, J. S. Epidemiological situation of bovine brucellosis after implementation of a vaccination program in Rio
Grande do Sul state, Brazil. Semina: Ciências Agrárias, Londrina, v. 37, n. 5, p. 3519-3520, 2016b. Suplemento 2.

SILVA, V. G. S. O.; DIAS, R.A.;FERREIRA, F.;AMAKU, M.; COSTA, E. L. S.; LOBO, J. R.; FIGUEIREDO, V. C. F.; GONÇALVES, V. S. P.; FERREIRA NETO, J. S. Situação epidemiológica da brucelose bovina no Estado de Sergipe. Arquivo Brasileiro de Medicina Veterinária e Zootecnia, Belo Horizonte, v. 61, p. 109-117, 2009. Suplemento 1.

SKUCE, R. A.; ALLEN, A. R.; MCDOWELL, S. W. J. Herd-level risk factors for bovine tuberculosis: a literature review Herd-level risk factors for bovine tuberculosis: a literature review. Veterinary Medicine International, v. 2012, Article ID 621210, p. 1-10, 2012. Available at: $<$ http://www.hindawi.com/journals/vmi/2012/621210/ abs/>. Accessed at: 05 july 2016.

SOUZA, V. A. F.; FERREIRA NETO, J. S.; AMAKU, M.; DIAS, R. A.; TELLES, E. O.; GRISI-FILHO, J. H. H.; HEINEMANN, M. B.; FERREIRA, F. Mathematical modeling of bovine brucellosis control using the RB51 vaccine. Semina: Ciências Agrárias, Londrina, v. 37, n. 5, p. 3767-3776, 2016. Suplemento 2.

TSCHOPP, R.; SCHELLING, E.; HATTENDORF, J.; ASEFFA, A.; ZINSSTAG, J. Risk factors of bovine tuberculosis in cattle in rural livestock production systems of Ethiopia. Preventive Veterinary Medicine, Colorado, v. 89, n. 3-4, p. 205-11, 2009.

VELOSO, F. P.; BAUMGARTEN, K. D.; MOTA, A. L. A. A.; FERREIRA, F.; FERREIRA NETO, J. S.; GRISI-FILHO, J. H. H.; DIAS, R. A.; AMAKU, M.; TELLES, E. O.; HEINEMANN, M. B.; GONÇALVES, V. S. P. Prevalence and herd-level risk factors of bovine tuberculosis in the State of Santa Catarina, Brazil. Semina: Ciências Agrárias, Londrina, v. 37, n. 5, p. 3659-3672, 2016. Suplemento 2.

VENDRAME, F. B.; AMAKU, M.; FERREIRA, F.; TELLES, E. O.; GRISI-FILHO, J. H. H.; GONÇALVES, V. S. P.; HEINEMANN, M. B.; FERREIRA NETO, J. S.; DIAS, R. A. Epidemiologic characterization of bovine tuberculosis in the State of Rondônia, Brazil. Semina: Ciências Agrárias, Londrina, v. 37, n. 5, p. 3639-3646, 2016. Suplemento 2.

VILLAR, K. S.; AMAKU, M.; DIAS, R. A.; FERREIRA NETO, J. S.; BENITEZ, F.; GONÇALVES, V. S. P.; FIGUEIREDO, V. C. F.; LOBO, J. R.; FERREIRA, F. Situação epidemiológica da brucelose bovina no Estado de Rondônia. Arquivo Brasileiro de Medicina Veterinária e Zootecnia, Belo Horizonte, v. 61, p. 85-92, 2009. Suplemento 1. 